\title{
Shear Capacity of Non-Metallic (FRP) Reinforced Concrete Beams with Stirrups
}

\author{
Noor Azlina Abdul Hamid, Rendy Thamrin, and Azmi Ibrahim
}

\begin{abstract}
This study presents test results of simply supported concrete beams longitudinally reinforced either by steel or glass fiber-reinforced polymer (GFRP). A total of sixteen large-scale concrete beams with steel stirrups were constructed and tested under four-point monotonic loading until failure. Half of the beams were longitudinally reinforced with GFRP bars, while the other half was reinforced with conventional steel bars as control specimens. To examine the shear behavior of the GFRP reinforced concrete (RC) beams, the main parameters investigated in the study included shear span-effective depth ratios, longitudinal reinforcement ratios and stirrup ratios. Two modes of failure, namely flexure and shear were observed. Due to low modulus elasticity of FRP bars, it was found that lesser shear strength resulted in concrete beams reinforced with GFRP bars compared to beams reinforced with steel bars. Moreover, the influence of the shear span-effective depth ratios and longitudinal reinforcement ratios significantly affect the distribution of internal forces in GFRP reinforced concrete beams. The test results correlated well with the prediction values provided by standard codes and design guidelines except in the case of GFRP reinforced concrete beams failed on shear.
\end{abstract}

Index Terms-Concrete beams, Glass fiber-reinforced polymer, shear, stirrup

\section{INTRODUCTION}

The use of fiber-reinforced polymer (FRP) as an alternative of reinforcing materials has become accepted in construction industry. Not like steel, properties of FRP reinforcement offers an outstanding performance for concrete that have high strength-to-weight ratios (10 to 15 times than steel), non-magnetic and provides excellent corrosion resistant which can lead to lower life-cycle costs [1], [2].

Commercially, FRP bars are available in different types of fiber including carbon (CFRP), aramid (AFRP) and glass (GFRP). Among these types of fiber, GRFP is the least expensive and the lowest tensile modulus of elasticity (typically 40 to $55 \mathrm{GPa}$ ) which possibly applied as non-prestressed reinforcement [3], [4]. Several investigations has been conducted to reveal that FRP bars can be used as alternative of reinforcing materials in concrete structures [5]-[8]. However, due to brittle elastic failure and low

Manuscript received February 10, 2013; revised June 4, 2013. This work was supported in part by the University Teknologi Mara under Grant 600-RMI/ST/DANA 5/3/Dst (449/2011).

N. A. Abdul Hamid was with the Faculty of Civil and Environmental Engineering, University Tun Hussein Onn Malaysia, Batu Pahat, Johor. She is now with the Faculty of Civil Engineering, University Teknologi Mara, Shah Alam, Selangor as a Ph.D. student (e-mail: azlinah@uthm.edu.my).

R. Thamrin was with University Tun Hussein Onn Malaysia, Batu Pahat, Johor. He is now with the Faculty of Civil Engineering, University Andalas, Padang, Indonesia (e-mail: rendy@ft.unand.ac.id).

A. Ibrahim is with the Faculty of Civil Engineering, University Teknologi Mara, Shah Alam, Selangor (e-mail: azmii716@yahoo.com). modulus of elasticity of FRP, the performance of FRP RC beams become one of the main issues to overcome. Different mechanical properties between FRP and conventional steel bars may affect the shear carrying mechanism in concrete beams. More rapid deterioration in shear can be observed in concrete beams longitudinally reinforced by steel rather than those reinforced by FRP due to the reduction shear resistance offered by un-cracked concrete, $V_{c}$ [9], [10]. The shear resistance of FRP RC beams also influences by the size-effect and shear-span-to-depth ratios [10], [11]. The experimental results on the ratios of the reinforcement indicated that the beams provided with stirrups and multiple layers of flexural reinforcement is recommended in order to resist the weak bend area of FRP stirrup cages [12]. The similar response also observed in the case of GFRP RC beams without stirrups such that shear strength increases as the amount of longitudinal GFRP bars increases [13], [14].

Furthermore, due to relatively high tensile strength of FRP reinforcements, some amount of tensile forces significantly distributed and expand to the support after the occurrence of diagonal shear cracks [15]. Hence, a careful anchorage design is needed in order to avoid bond failure. Meanwhile, the existing design codes and guidelines gave unconservative prediction of the shear strength of FRP RC beams which have low shear span-to-depth ratio $(a / d)$ less than 2.5 and effective depth, $d$ less than $300 \mathrm{~mm}$ [16], [17]. This may be attributed to the design formulas adopted from steel RC members with some modifications to account for the substantial of FRP reinforcements.

The main aim of the study is to investigate the influence of shear span-to-depth ratios $(a / d)$ less and more than 2.5, longitudinal reinforcement ratios and stirrups spacing on the shear resistance of GFRP RC beams. All experimental results were compared with the calculated prediction design codes according to BS8110 [17], ACI 318-08 [18] and ACI 440.1R-06 [19].

\section{EXPERIMENTAL PROGRAM}

\section{A. Material Properties}

The beams were cast on the same day from the same ready-mix concrete batch with a compressive strength of 24 $\mathrm{MPa}$ on 28 days, with a maximum aggregate size of $20 \mathrm{~mm}$. Conventional steel reinforcing bars as well as sand-coated GFRP V-Rods (Fig. 1) were used as longitudinal reinforcement in concrete beams. Two types of beam were constructed and tested, steel RC beams (BSM) and GFRP RC beams (BGM). Both top and bottom longitudinal bars in the BSM beams consisted of $16 \mathrm{~mm}$ diameter of high strength steel bars, while GFRP reinforcing bars were used in the BGM beams and had the equivalent diameter as steel bars. 
All the beams were provided with $8 \mathrm{~mm}$ diameter closed rectangular steel stirrups (mild steel) spaced at 50 and 150 $\mathrm{mm}$ in the shear span zone as these two types of spacing were checked using BS8110 codes to provide the minimum and sufficient amount of stirrups, respectively. The properties of reinforcement bars are summarized in Table I. The mechanical properties of GFRP bars were adopted from the specification provided by manufacturers.

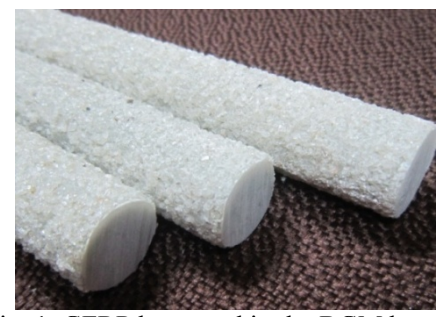

Fig. 1. GFRP bars used in the BGM beams.

TABLE I: PROPERTIES OF REINFORCING BARS

\begin{tabular}{lcccc}
\hline $\begin{array}{l}\text { Bar } \\
\text { type }\end{array}$ & $\begin{array}{c}\text { Diameter, } \\
\mathrm{mm}\end{array}$ & $\begin{array}{c}\text { Tensile } \\
\text { strength, MPa }\end{array}$ & $\begin{array}{c}\text { Modulus of } \\
\text { elasticity, GPa }\end{array}$ & $\begin{array}{c}\text { Ultimate } \\
\text { strain }\end{array}$ \\
\hline GFRP & 16 & 736 & 56.8 & 0.016 \\
Steel & 16 & 512 & 207 & 0.0026 \\
Steel & 8 & 440 & 162 & 0.0028 \\
\hline \hline
\end{tabular}

\section{B. Test Specimens}

A total of sixteen full-scale RC beams were constructed and tested monotonically up to failure. The beams were rectangular cross section with $200 \mathrm{~mm}$ wide and $400 \mathrm{~mm}$ deep as shown in Fig. 2. To study the influence of shear span-effective depth ratio $(a / d)$, two types of $a / d$ ratios, 1.5 and 3.0, which is less and more than 2.5 respectively, were examined. In all cases, the sufficient concrete cover to the centroid of the reinforcement bars is $38 \mathrm{~mm}$. The beams were designed according to available standard codes and design guidelines.

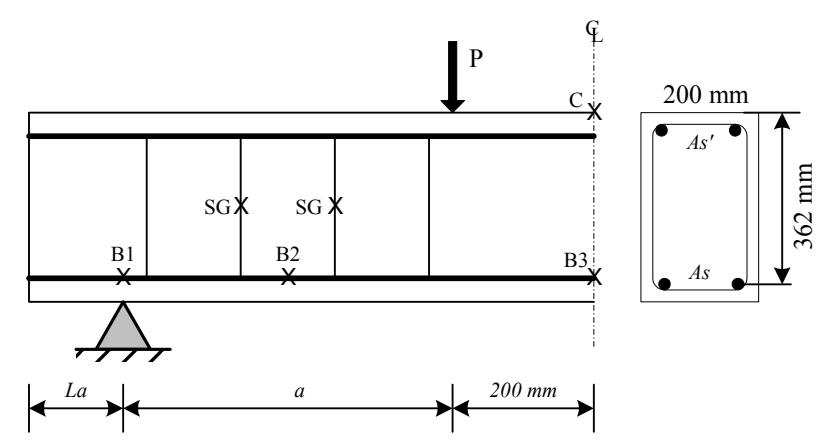

Fig. 2. Beam dimensions and strain gauge positions.

In the case of beams reinforced by conventional steel bars, two design codes of BS8110 [17] and ACI 318-08 [18] were referred. Since the designation of FRP RC beams are slightly differ from steel RC beams, the code provisions according to ACI 440.1R-06 [19] was used. As reported in Table II, two different reinforcement ratios of $0.6 \%$ and $0.8 \%$ were considered. The failure mode of BGM beams were predicted according to ACI 440.1R-06 by comparing the reinforcement ratios from equation (1) with the balanced reinforcement ratios using (2) that considering its design tensile strength as follows:

$$
\rho_{f}=A_{f} / b d
$$

$$
\rho_{f b}=0.85 \beta_{1} \frac{f_{c}}{f_{f u}} \frac{E_{f} \varepsilon_{c u}}{E_{f} \varepsilon_{c u}+1}
$$

where, $\beta_{l}=0.85$ if $f_{c} \leq 28 \mathrm{MPa}, f_{f u}=$ tensile strength of FRP $(\mathrm{MPa}), E_{f}=$ modulus elasticity of FRP $(\mathrm{MPa})$ and $\varepsilon_{c u}=$ ultimate strain in concrete. In this study, the design of FRP $\mathrm{RC}$ beams is totally to replace the used of longitudinal steel bars in concrete beams. Hence, similar beam dimensions and reinforcement areas were provided in both specimens BSM and BGM. While, the failure mode of specimens BSM are governs by steel yielding before the compressive strains in the concrete reached the maximum strain value of 0.0035 [20].

\section{Test Setup}

The beams were tested monotonically under four point bending by means of 500 and $1000 \mathrm{kN}$ hydraulic actuator. Each beam was loaded continuously to failure with each load increments approximately 5\% from its theoretical ultimate load. A part of operation was manually controlled and some necessary adjustments were made to keep the load constantly during the test. The electrical-resistance strain gauges were used to measure tensile strains along reinforcing bars, stirrups and compressive area in concrete with a $5 \mathrm{~mm}$ long, $3 \mathrm{~mm}$ long and $60 \mathrm{~mm}$ long, respectively. Fig. 2 shows the strain gauge positions along the reinforcing bars and denoted as B1, B2 and B3. Whereas strain gauges denoted as SG were attached on selected stirrups. Concrete strain gauges were also bonded at the top compression surface at the mid-span and indicated as C. All the strain gauges were fully wrapped and waterproofed before casting. To measure the deflection of the beam, three linear variable displacement transducers (LVDTs) with a $50 \mathrm{~mm}$ stroke were placed at the mid-span and under the load positions. During the test, all crack formation and propagation on both sides of the beam surfaces were marked and labelled with the corresponding incremental loads.

\section{TEST RESUlts AND DisCUSSION}

The typical failure mode of the beam is illustrated in Fig. 3, whereas Table III summarized the prediction and experimental results of all the tested beams. Beam failed on diagonal tension shear experienced formation of diagonal crack in the shear span zone followed by concrete crushing in the loading point zone (BGM-03), sudden formation of diagonal crack in the shear span zone followed by beam failure (BGM-04) or formation of diagonal crack growth gradually in the shear span zone followed by beam failure after yielding of longitudinal reinforcement (BSM-03 and BSM-04). While other beams which failed on flexural experienced by rupture of tensile longitudinal reinforcement or concrete crushing on the top of compression zone. For both beam types, the amount of flexural crack in case of beam with shorter shear span length less than that beam with longer shear span length. Also, the occurrence of diagonal shear crack was not clearly seen in the shear span zone.

Fig. 4 clearly shows that the deflection of BGM beams is higher than that BSM beams, which this behaviour is attributed to the low modulus elasticity of GFRP bars that may influenced the stiffness of the beam significantly. It also indicates that lesser shear span-effective depth ratios and higher amount of longitudinal reinforcement significantly 
increase the experimental ultimate loads. On the other hand, because of higher tensile strength of GFRP bars, the capacity of BGM is slightly higher than BSM, except in the case of beams failed on shear (BGM-03 and BGM-04) which is in good agreement with other test results [21]. However, the characteristics of shear failure between GFRP and steel RC beams are similar.

TABLE II: DETAILS OF TEST BEAMS AND VARIABLES

\begin{tabular}{|c|c|c|c|c|c|c|c|c|c|c|c|}
\hline \multirow[t]{2}{*}{ Specimens } & \multirow{2}{*}{$\begin{array}{c}a \\
(\mathrm{~mm})\end{array}$} & \multirow[t]{2}{*}{$a / d$} & \multirow{2}{*}{$\begin{array}{c}L \\
(\mathrm{~mm})\end{array}$} & \multirow{2}{*}{$\begin{array}{c}L_{a} \\
(\mathrm{~mm})\end{array}$} & \multirow{2}{*}{$\begin{array}{l}L_{\text {total }} \\
(\mathrm{mm})\end{array}$} & \multicolumn{2}{|c|}{$\begin{array}{l}\text { Shear Reinforcement } \\
\text { (mild steel } 8 \mathrm{~mm} \text { dia.) }\end{array}$} & \multicolumn{4}{|c|}{ Longitudinal Reinforcement Bars } \\
\hline & & & & & & $\mathrm{s}(\mathrm{mm})$ & $\rho_{s}(\%)$ & Type & $\mathrm{N}$ & $A_{s}$ and $A_{s}{ }^{\prime}$ & $\rho_{\mathrm{s}}$ and $\rho_{\mathrm{s}}{ }^{\prime}(\%)$ \\
\hline BSM-01 & 2550 & 1.5 & 1500 & 250 & 2000 & 50 & 1.01 & Steel & 2 & 402.1 & 0.6 \\
\hline BSM-02 & 550 & 1.5 & 1500 & 250 & 2000 & 50 & 1.01 & Steel & 3 & 603.2 & 0.8 \\
\hline BSM-03 & 550 & 1.5 & 1500 & 250 & 2000 & 150 & 0.34 & Steel & 2 & 402.1 & 0.6 \\
\hline BSM-04 & 550 & 1.5 & 1500 & 250 & 2000 & 150 & 0.34 & Steel & 3 & 603.2 & 0.8 \\
\hline BSM-05 & 1100 & 3.0 & 2600 & 200 & 3000 & 50 & 1.01 & Steel & 2 & 402.1 & 0.6 \\
\hline BSM-06 & 1100 & 3.0 & 2600 & 200 & 3000 & 50 & 1.01 & Steel & 3 & 603.2 & 0.8 \\
\hline BSM-07 & 1100 & 3.0 & 2600 & 200 & 3000 & 150 & 0.34 & Steel & 2 & 402.1 & 0.6 \\
\hline BSM-08 & 1100 & 3.0 & 2600 & 200 & 3000 & 150 & 0.34 & Steel & 3 & 603.2 & 0.8 \\
\hline BGM-01 & 550 & 1.5 & 1500 & 250 & 2000 & 50 & 1.01 & GFRP & 2 & 402.1 & 0.6 \\
\hline BGM-02 & 550 & 1.5 & 1500 & 250 & 2000 & 50 & 1.01 & GFRP & 3 & 603.2 & 0.8 \\
\hline BGM-03 & 550 & 1.5 & 1500 & 250 & 2000 & 150 & 0.34 & GFRP & 2 & 402.1 & 0.6 \\
\hline BGM-04 & 550 & 1.5 & 1500 & 250 & 2000 & 150 & 0.34 & GFRP & 3 & 603.2 & 0.8 \\
\hline BGM-05 & 1100 & 3.0 & 2600 & 200 & 3000 & 50 & 1.01 & GFRP & 2 & 402.1 & 0.6 \\
\hline BGM-06 & 1100 & 3.0 & 2600 & 200 & 3000 & 50 & 1.01 & GFRP & 3 & 603.2 & 0.8 \\
\hline BGM-07 & 1100 & 3.0 & 2600 & 200 & 3000 & 150 & 0.34 & GFRP & 2 & 402.1 & 0.6 \\
\hline BGM-08 & 1100 & 3.0 & 2600 & 200 & 3000 & 150 & 0.34 & GFRP & 3 & 603.2 & 0.8 \\
\hline
\end{tabular}

TABLE III: COMPARISON OF PREDICTED AND EXPERIMENTAL RESULTS

\begin{tabular}{|c|c|c|c|c|c|c|c|c|c|c|c|c|c|c|c|}
\hline \multirow{2}{*}{\multicolumn{2}{|c|}{ Specimens $\frac{\begin{array}{c}\text { Experimental } \\
\text { shear }\end{array}}{V_{\text {exp. }}(\mathrm{kN})}$}} & \multicolumn{8}{|c|}{ ACI 318-08 } & \multicolumn{4}{|c|}{ ACI 440.1R-06 } & \multirow{2}{*}{$\begin{array}{l}\text { Experimental } \\
\text { maximum } \\
\text { deflection } \\
(\mathrm{mm})\end{array}$} & \multirow[t]{2}{*}{$\begin{array}{c}\text { Failure } \\
\text { mode }\end{array}$} \\
\hline & & $\begin{array}{c}V_{c} \\
(\mathrm{kN})\end{array}$ & $\begin{array}{c}V_{s} \\
(\mathrm{kN})\end{array}$ & $\begin{array}{c}V_{\text {pred. }} \\
(\mathrm{kN})\end{array}$ & $\begin{array}{c}P f \\
(k N)\end{array}$ & $\begin{array}{c}V_{c} \\
(\mathrm{kN})\end{array}$ & $\begin{array}{c}V_{s} \\
(k N)\end{array}$ & $\begin{array}{c}V_{\text {pred }} \\
(k N)\end{array}$ & $\operatorname{Pf}(k N)$ & $\begin{array}{c}V_{c} \\
(k N)\end{array}$ & $\begin{array}{c}V_{s} \\
(k N)\end{array}$ & $\begin{array}{c}V_{\text {pred. }} \\
(\mathrm{kN})\end{array}$ & $\operatorname{Pf}(k N)$ & & \\
\hline BSM-01 & 157.6 & \multirow{8}{*}{59} & 320 & 379 & 126 & 48 & 320 & 368 & 124 & & & & & 10.92 & Flexure \\
\hline BSM-02 & 258.7 & & 320 & 379 & 182 & 55 & 320 & 375 & 176 & & & & & 25.47 & Flexure \\
\hline BSM-03 & 195.5 & & 107 & 166 & 126 & 48 & 107 & 155 & 124 & & & & & 13.66 & Shear \\
\hline BSM-04 & 223.3 & & 107 & 166 & 182 & 55 & 107 & 162 & 176 & & & & & 11.35 & Shear \\
\hline BSM-05 & 71.8 & & 320 & 379 & 63 & 48 & 320 & 368 & 62 & & & & & 34.17 & Flexure \\
\hline BSM-06 & 122.3 & & 320 & 379 & 91 & 55 & 320 & 375 & 88 & & & & & 19.18 & Flexure \\
\hline BSM-07 & 86.4 & & 107 & 166 & 63 & 48 & 107 & 155 & 62 & & & & & 23.97 & Flexure \\
\hline BSM-08 & 117.3 & & 107 & 166 & 91 & 55 & 107 & 162 & 88 & & & & & 21.85 & Flexure \\
\hline BGM-01 & 233.2 & & & & & & & & & 22 & 320 & 342 & 157 & 14.41 & Flexure \\
\hline BGM-02 & 281.6 & & & & & & & & & 26 & 320 & 346 & 183 & 21.06 & Flexure \\
\hline BGM-03 & 139.0 & & & & & & & & & 22 & 107 & 128 & 157 & 12.63 & Shear \\
\hline BGM-04 & 181.3 & & & & & & & & & 26 & 107 & 133 & 199 & 16.08 & Shear \\
\hline BGM-05 & 99.0 & & & & & & & & & 22 & 320 & 342 & 85 & 33.06 & Flexure \\
\hline BGM-06 & 132.1 & & & & & & & & & 26 & 320 & 346 & 99 & 37.07 & Flexure \\
\hline BGM-07 & 92.8 & & & & & & & & & 22 & 107 & 128 & 85 & 39.88 & Flexure \\
\hline BGM-08 & 125.6 & & & & & & & & & 26 & 107 & 133 & 99 & 43.74 & Flexure \\
\hline
\end{tabular}

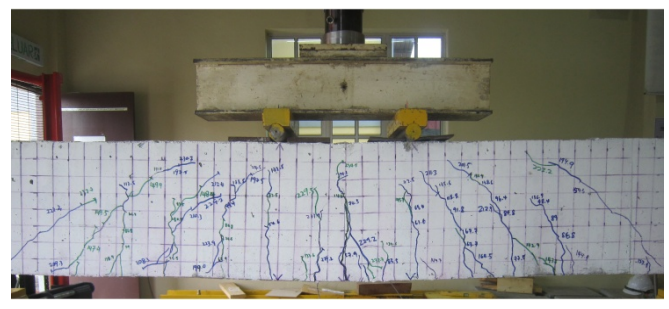

(a) Flexure failure mode (BSM-08)

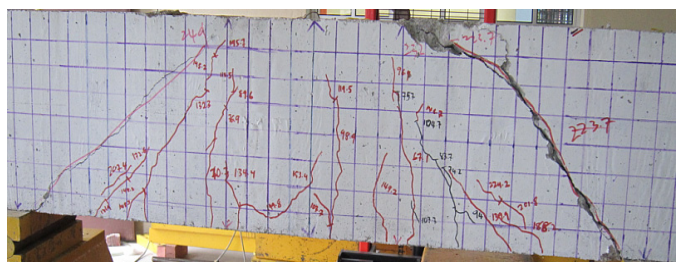

(b) Shear failure mode (BGM-03)

Fig. 3. Typical flexure and shear failure of the tested beams.
In order to verify the design provision in the codes, the test results of BSM were compared with recommended design codes according to BS8110 as the values of concrete shear capacity, $V_{c}$ is given,

$$
V_{c}=0.79\left(\frac{100 A_{s}}{b d}\right)^{1 / 3}\left(\frac{400}{d}\right)^{1 / 4}
$$

but $100 A_{s} / b d$ should not be taken if greater than 3 and $(400 / d)^{1 / 4}$ should not be taken if less than 1 for members with shear reinforcement. While, shear strength provided by shear reinforcement, $V_{s}$ is calculated as follow,

$$
V_{s}=\frac{A_{s v} f_{f v}}{b S_{v}}
$$

where $A_{s v}=$ cross-sectional area of stirrups $\left(\mathrm{mm}^{2}\right), f_{f v}=$ tensile strength of stirrups (MPa), $b=$ web width of beam $(\mathrm{mm})$ and 
$S_{v}=$ spacing of stirrups (mm). The total of $V_{c}$ and $V_{s}$ resulting the shear strength prediction, $V_{\text {pred. }}$ than that compared with the experimental ultimate loads, $V_{\text {exp }}$. As recommended by ACI 318-08, the concrete shear strength is given as,

$$
V_{c}=0.17 \sqrt{f_{c u}} b d
$$

where the shear strength provided by shear reinforcement is calculated by

$$
V_{s}=\frac{A_{s v} f_{f v} d}{S}
$$

To account the shear contribution of the concrete for GFRP $\mathrm{RC}$ beams, ACI 440.1R-06 recommended the following,

$$
V_{c}=\frac{2}{5} \sqrt{f_{c u}} b c
$$

where $\mathrm{c}$ is a cracked neutral axis depth ( $\mathrm{mm})$ and computed as $c=k d$ and $k=\sqrt{2 \rho_{f} n_{f}+\left(\rho_{f} n_{f}\right)^{2}}-\rho_{f} n_{f}$ such that $\rho_{f}$ is a
FRP reinforcement ratios of $A_{f} / b d$. Moreover, since the BGM beams were provided with steel stirrups, the equation in (6) shall be used.

The comparison between theoretical values and test results are shown in Fig. 5. In Fig. 5(a), it is shown that the calculated flexural capacities are considerably lower than that test results except for BGM-03 and BGM-04 (calculated using ACI 440.1R-06) which were slightly higher than test results and failed on shear. Moreover, Fig. 5(b) demonstrates that calculated shear capacity of the beams higher than test results except for beams which were failed on shear. This fact reveals that the shear failure was occurred in case of beams with lower stirrups ratio and shorter shear span length due to high intensity of shear force. On the other hand, flexural failure was occurred in case of beams with higher stirrups ratio and longer shear span length. Fig. 6 indicates the strain distribution between steel and GFRP reinforcement bars. It is clearly seen that the strain in BSM-02 (Fig. 6(a)) exceeds the yield strain at the middle zone of the beam at failure.
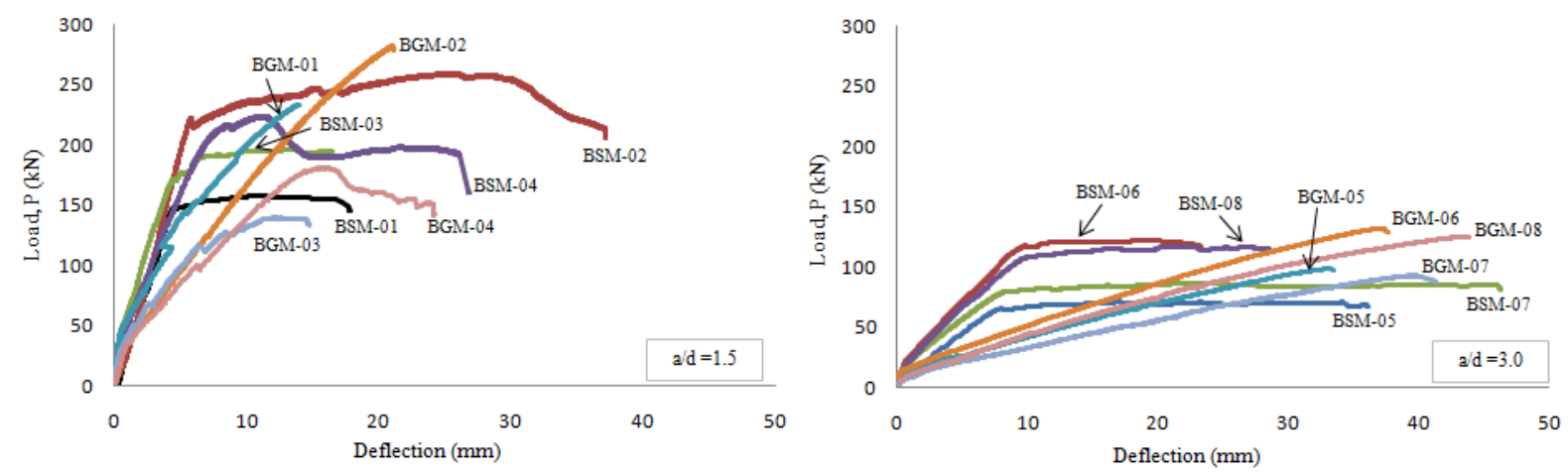

Fig. 4. Load-deflection curves of the tested beams.
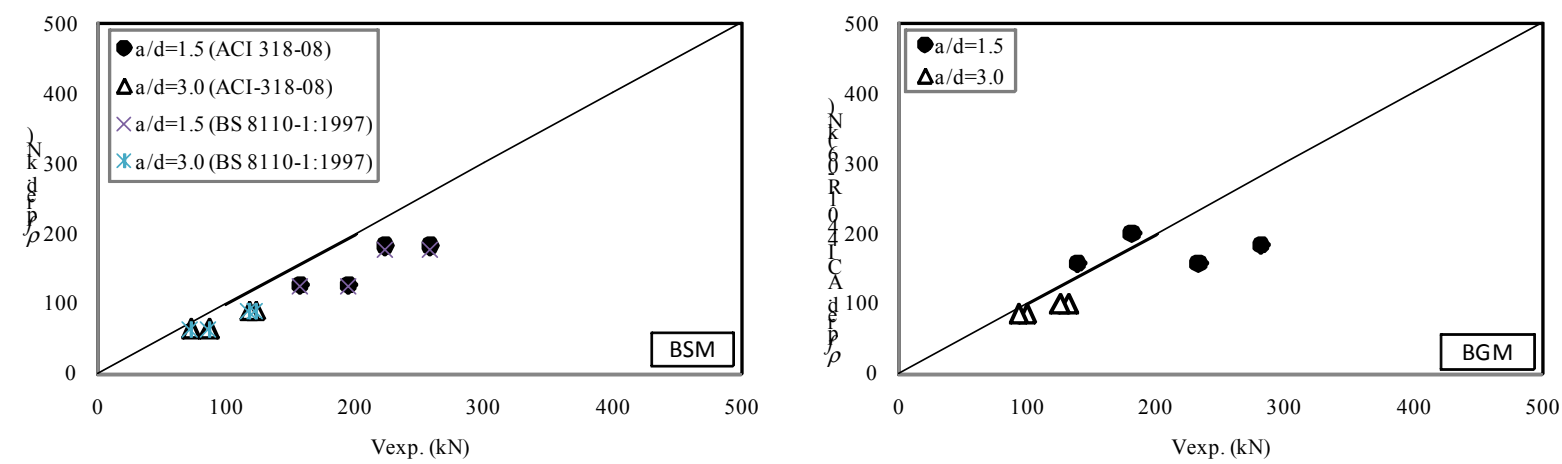

(a)
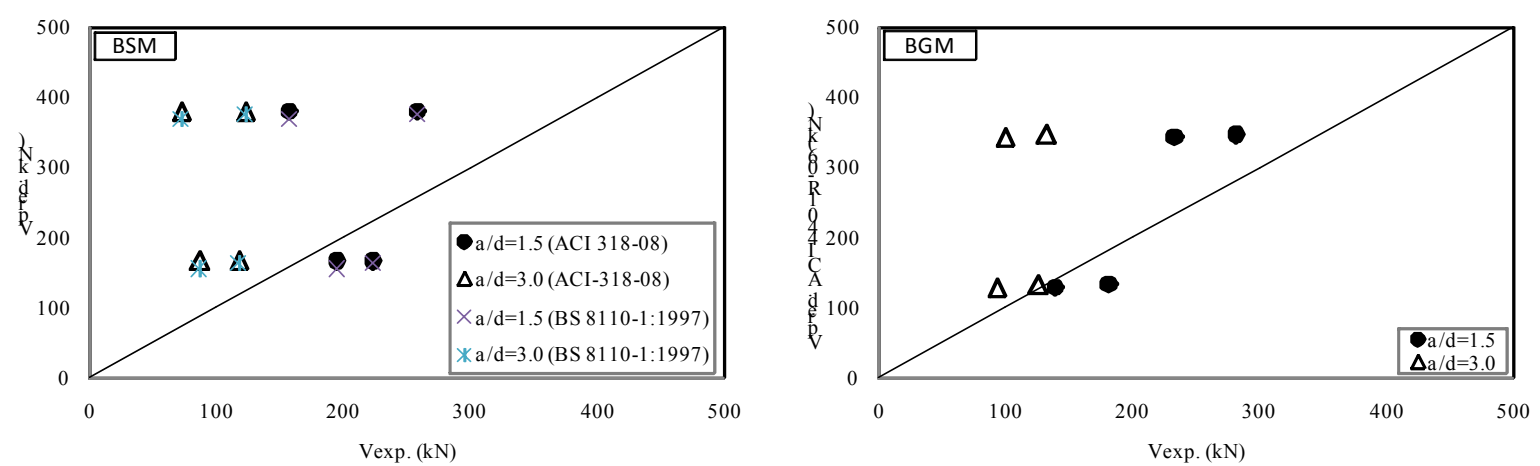

(b)

Fig. 5. Comparison of calculated: (a) flexural (b) shear capacity with experimental ultimate load. 


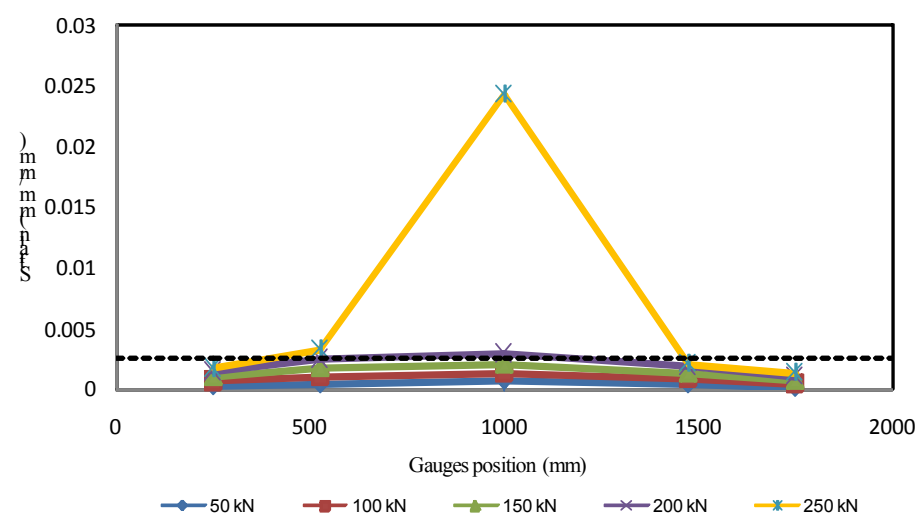

(a)

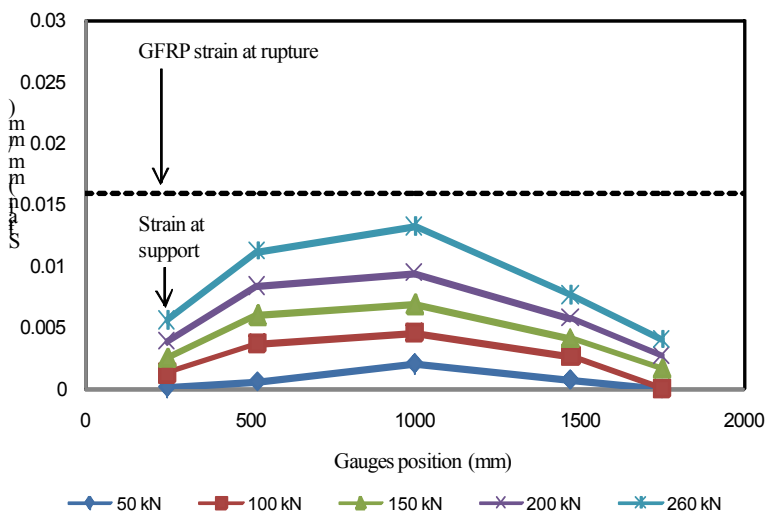

(b)

Fig. 6. Strain distribution along longitudinal reinforcement: (a) BSM-02 (b) BGM-02.

While at the support, the strains are very low and stop to increase after bar yield. Unlike in BGM-02, the strains along the bar are continue to increase until the beam reach the failure load and significant amount of strain is clearly detect at the supports of the beam. It is confirm that the strain behavior of longitudinal reinforcement in beam reinforced with GFRP bars totally different to that beams with steel bars.

\section{CONCLUSIONS}

The experimental results and analysis on 8 steel RC beams and 8 GFRP RC beams have been presented and discussed in this paper. As expected, all GFRP RC beams behaved linearly up until failure due to low plasticity in the reinforcement bars. In addition, the failure took place at large displacements compared to steel RC beams.

All the parameters chosen in the experimental programmed such as longitudinal reinforcement ratio, shear span length and stirrup ratios significantly affect the failure mode of the beam. In both types of beam, two modes of failure were observed which shows that shear failure occur in beam with low stirrup ratios and shorter shear span length. In contrast, flexural failure was occurred in case of beams with higher stirrups ratio and longer shear span length. Nevertheless, shear capacity of beams reinforced with GFRP bars is lower than that beams reinforced with steel bars which was also reveals from the calculated flexural capacities using ACI 440.1R-06.

The strain distribution along longitudinal reinforcement of beam reinforced with GFRP bars is totally different to that beam with steel bars. While, the strain on stirrups in beam reinforced with GFRP bars higher than that stirrups strain in beam reinforced with steel particularly in a beam with shorter shear span length.

\section{ACKNOWLEDGMENT}

The first authors wish to acknowledge the support provided by the entire laboratory technical staff member from Faculty of Civil, UTHM and UiTM.

\section{REFERENCES}

[1] M. A. Erki and S. H. Rizkalla, "A sample of international production: FRP reinforcement for concrete structure," Concrete International, pp. 48-52, June 1993.
[2] L. C. Bank, "Properties of FRP reinforcements for concrete," Concrete Structures: Properties and Aplications, pp. 59-86, 1993.

[3] B. Benmokrane, O. Chaallal, and R. Masmoudi, "Glass fibre reinforced plastic (GFRP) rebars for concrete structures," J. Constr. and Building Materials, vol. 9, no. 6, pp. 353-364, 1995.

[4] F. Micelli and A. Nanni, "Tensile characterization of FRP rods for reinforced concrete structures," J. Mechanics of Composite Materials, vol. 39 , no. 4, pp. 293-304, 2003.

[5] F. M. Wegian and H. A. Abdalla, "Shear capacity of concrete beams reinforced with fiber reinforced polymers," J. Composite Structures, vol. 71, pp. 130-138, 2005.

[6] A. F. Ashour, "Flexural and shear capacities of concrete beams reinforced with GFRP bars," J. Construc. and Building Materials, vol. 20, pp. 1005-1015, 2006.

[7] M. Guadagnini, Pilakoutas, and P. Waldron, "Shear resistance of FRP RC beams : Experimental study," J. Composites for Construction, vol. 10, no. 6, pp. 464-473, Dec 2006.

[8] Task Group 9.3, "FRP reinforcement in RC structures: Design and use of fibre reinforced polymer reinforcement (FRP) in reinforced concrete structures, " Technical Report: fib CEB-FIP, pp. 16, Sept 2007.

[9] A. G. Razaqpur, M. Shedid, and B. Isgor, "Shear strength of Fiber-reinforced polymer reinforced concrete beams subject to unsymmetric loading," J. Composites for Construction, vol. 11, no. 4, pp. 500-512, Aug 2011.

[10] A. K. El-Sayed, E. F. El-Salakawy, and B. Benmokrane, "Shear strength of FRP-reinforced concrete beams without transverse reinforcement," ACI Struct. J., pp. 235-243, Mac-Apr 2006.

[11] E. C. Bentz, L. Massam, and M. P. Collins, "Shear strength of large concrete members with FRP reinforcement," J. Composites for Constuc., vol. 14, no. 6, pp. 637-646, Dec 2010.

[12] T. Alkhrdaji, M. Wideman, A. Belarbi, and A. Nanni, "Shear strength of GFRP RC beams and slabs," in Proc. CCC, 2001, Portugal.

[13] R. Thamrin, A. A. Abdul Samad, Y. E. C David, and N. A. Abdul Hamid, "Experimental study on diagonal shear cracks of concrete beams without stirrups longitudinally reinforced with GFRP bars," in Proc. FIB Symposium, Prague, 2011.

[14] R. Thamrin, "Tension force model of longitudinal reinforcement at the support of RC beam with hanging region," in Proc. of FIB Symposium, Budapest, Hungary, 2005.

[15] M. S. Alam and A. Hussein, "Unified shear design equation for FRP reinforced concrete members without stirrups," J. Composites for Construc., Oct 2012.

[16] M. S. Alam and A. Hussein, "Size effect on shear strength of FRP reinforced concrete beams without stirrups," J. Composites for Construc. Nov 2012.

[17] British Standard Institution (BSI), BS 8110-1: 1997 Structural Use of Concrete, Code of Practice for Design and Construction, Part 1, BSI, pp. 172, 1997.

[18] American Concrete Institut (ACI), Building Code Requirements for Structural Concrete (ACI 318-08) and Commentary, American Concrete Institute, Farmington Hills (MI), pp. 465, 2008.

[19] American Concrete Institut (ACI), Guide for the Design and Construction of Structural Concrete Reinforced with FRP Bars (440-1R-06), pp. 44, 2006.

[20] P. Bhatt, T. J. MacGinley, and B. S. Choo, Reinforced Concrete, Design Theory and Examples, 3rd ed. Taylor \& Francis, 2006, pp. 583.

[21] J. R. Yost, S. P. Gross, and D. W. Dinehart, "Shear strength of normal concrete beams reinforced with deformed GFRP bars," J. Composites for Construc. vol. 5, no. 4, pp. 268-275, Nov 2001. 


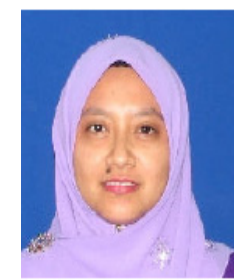

Noor Azlina Abdul Hamid was born in Johor, Malaysia in 1979. She's graduated from University Teknologi Malaysia (UTM), Malaysia for Degree and Master (Civil-Structure) Engineering in 2001 and 2005, respectively. Currently, as a full-time $\mathrm{PhD}$ students at the Faculty of Civil Engineering, University Teknologi Mara (UiTM), Shah Alam, Malaysia in the field of FRP reinforced concrete members.

She had served as a structural engineer in consultancy for two years and currently as a lecturer of the Faculty of Civil and Environmental Engineering, University Tun Hussein Onn Malaysia since 2006. Subject taught i.e. construction and materials, static and dynamic, mechanics of materials and design of reinforced concrete structures.

Ms. Azlina has completely presented several papers at international conferences mostly on shear performance of FRP-reinforced concrete beam which supported by numerous research grants. Moreover, she is a member of Board of Engineers Malaysia (BEM).

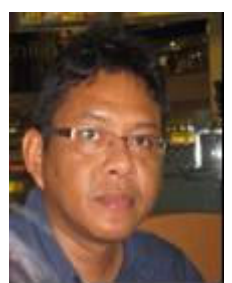

Rendy Thamrin was born in Padang, Indonesia in 1969. He obtained a PhD in Structural Engineering (Reinforced Concrete Structure) from Toyohashi University of Technology, Japan in March 2006.

As a senior lecturer at the Faculty of Civil Engineering, University Andalas, Indonesia, he had an experienced on teaching and research almost 15 years. He had also been a senior lecturer of University Universiti Tun Hussein Onn Malaysia for 3 years and held as a Head of Structural Laboratory. Subject taught i.e. static and dynamic, mechanics of materials, structural analysis, software and programming and design of reinforced concrete structures

Dr. Rendy has completely published more than 10 articles in international conferences and written articles in journals. He is actively involved in research in the field of FRP reinforced concrete beams in terms of flexure, shear and bond failure and sponsored by several research grants. In addition, he is also actively involved as external examiners either Masters or Doctoral candidates and supervising post-graduates students.

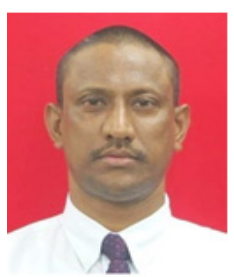

Azmi Ibrahim was born in Penang, Malaysia in 1963. He obtained a PhD from University of Sussex, United Kingdom in 1995 on structural engineering fields.

$\mathrm{He}$ is currently a Professor at the Faculty of Civil Engineering, University Teknologi Mara (UiTM), Malaysia and held as a Dean. He had been involved with UiTM since 1986 with an experienced on teaching and research projects more than 25 years. Subject taught i.e. steel structures, software and programming and design of reinforced concrete structures.

Prof. Azmi has published more than 10 articles in international conferences and journals. He was awarded numbers of research grant and also involved with an extensive research projects with industry. In addition, he is frequently invited as external examiners either Masters or Doctoral candidates and also supervising post-graduates students of UiTM. Actively as a member of Concrete Malaysia (PERKOM), Permanent Rail Institute, Board of Engineers Malaysia (BEM), Malaysian Structural Steel Association (MSSA), International Association of Concrete technology (IACT) and Malaysian Society for Non Destructive testing (MSNT). 